\title{
PREZENTACJA RĘKOPIŚMIENNYCH SAKRAMENTARZY I MSZA- ŁÓW PRZEDTRYDENCKICH, TORUŃ DNIA 18.12.2017 R.
}

W dniu 18 grudnia 2017 r. na Wydziale Teologicznym UMK w Toruniu odbyła się uroczysta prezentacja rękopiśmiennych sakramentarzy i mszałów przedtrydenckich, opracowanych przez Księdza Biskupa Andrzeja Suskiego, pierwszego biskupa diecezji Toruńskiej, założyciela i długoletniego kanclerza Wydziału Teologicznego Uniwersytetu Mikołaja Kopernika w Toruniu. Poniżej zamieszczamy pełny tekst tej prezentacji, której dokonał ks. prof. zw. dr hab. Krzysztof Konecki, kierownik Katedry Teologii Praktycznej tegoż Wydziału.

\section{EKSCELENCJE, SZANOWNI PAŃSTWO}

Przypadł mi w udziale wyjątkowy zaszczyt i niezwykłe wyróżnienie zaprezentowania Państwu dwu monumentalnych dzieł opracowanych

* Ks. prof. zw. dr hab. Krzysztof Konecki jest kierownikiem Katedry Teologii Praktycznej na Wydziale Teologicznym UMK w Toruniu oraz założycielem i redaktorem naukowym wydziałowego kwartalnika „Teologia i Człowiek” (kkkonecki@o2.pl). 
przez Księdza Biskupa Andrzeja Suskiego pierwszego biskupa diecezji Toruńskiej, założyciela i długoletniego kanclerza Wydziału Teologicznego Uniwersytetu Mikołaja Kopernika w Toruniu.

Pierwsze to Sakramentarze. Przewodnik po rękopisach. Fontes scrutari I, Wyd. Adam Marszałek, Toruń 2016, ss. 1023 i drugie dzieło, będące kontynuacją i w pewnym sensie dopełnieniem pierwszego, Rękopiśmienne mszały przedtrydenckie. Katalog sumaryczny. Fontes scrutari II, Wyd. A. Marszałek, Toruń 2017, ss. 811.

Temat pierwszej księgi jednoznacznie zapowiada, że jej treścią są katalogi rękopiśmiennych sakramentarzy, względnie ich fragmentów. Jak wiadomo, sakramentarz jako odrębna księga używany był w liturgii między VII a XII wiekiem. Od początku II tysiąclecia chrześcijaństwa stanowił istotną część mszału (missale plenarium), którego całość dopełniały księgi lekcjonarza (wraz z ewangelistarzem), graduale oraz odpowiednie rubryki, będące uprzednio częścią osobnego ordines. Jak informuje nas na wstępie sam Autor księgi, dzieło to opisuje 1179 sakramentarzy lub ich zachowanych fragmentów. Pochodzą one z 14 krajów, a znajdują się oczywiście w wielu więcej krajach, np. w USA czy w Polsce (Gniezno, Warszawa, Wrocław). Miejsca przechowywania analizowanych źródeł są różnorakie i Autor dzieła nam je precyzyjnie umiejscowił. Chodzi tu także o archiwa, jak biblioteki krajowe, regionalne, miejskie, królewskie, książęce, uniwersyteckie, diecezjalne, katedralne, kapitulne, zakonne, parafialne itd. Ponadto każdy rękopiśmienny dokument opatrzony jest takimi precyzyjnymi danymi, jak: sygnatura, liczba kart rękopisu i ich wymiary podane w milimetrach, wskazanie na liturgiczny typ sakramentarza, czas powstania dokumentu i miejsce jego pochodzenia, rok jego ewentualnego drukowanego wydania, zestaw bibliograficznych pozycji zawierających odniesienia do analizowanego dokumentu. Najobszerniejszą częścią zdecydowanej większości rękopiśmiennych źródeł jest opis zawartości treściowej danego sakramentarza lub jego fragmentu. Opierano się przy tym na wcześniej wydanych opracowaniach lub też na odczytach z mikrofilmów. Dotyczyło to około 40 kodeksów. O pracochłonności i rzetelności tego ostatniego elementu świadczą np. opisy zawartości niektórych kodeksów, które obejmują nawet 10 stron (s. 985-994, n. 1171 - Sacramentarium Triplex z państwowego Archiwum w Zürichu). 
Zestaw pozycji bibliograficznych odnoszących się do określonych sakramentarzy (lub ich fragmentów), wykorzystany i precyzyjnie podany przy jednostkowym kodeksie, jest zaiste imponujący. Obejmuje on ponad dwa tysiące pozycji (!), publikowanych nie tylko w głównych europejskich językach (angielski, francuski, hiszpański, niemiecki, włoski), ale również w języku chorwackim, słoweńskim, a także polskim (zob. m.in. publikacje takich autorów jak Boguniowski, Niedźwiecki, Rył, Sokołowski itd.). O znajomości języka łacińskiego nie wspominamy, gdyż jest on fundamentalnym językiem analizowanych kodeksów.

Dla pełni obrazu należy przypomnieć, że zestaw i katalog opisanych 1179 sakramentarzy lub ich fragmentów wskazuje równocześnie na miejsce ich aktualnego przechowywania. Obejmują one aż 236 miejscowości, zarówno w Europie, jak też prawie 20 lokalizacji w USA, a także z Polski (Gniezno, Warszawa, Wrocław).

Bibliografię oraz katalogi sakramentarzy poprzedza obszerne wprowadzenie w postaci pogłębionego artykułu na temat sakramentarzy autorstwa ks. prof. dra hab. Jana Miazka. Sakramentarz jest księgą liturgiczną przeznaczoną dla celebransa, biskupa lub prezbitera, powstał w Rzymie w VII wieku. Księga zawiera modlitwy mszalne, teksty związane z udzielaniem sakramentów i sprawowaniem innych obrzędów liturgicznych. W literaturze patrystycznej i w liturgii starożytnej słowem sacramenta określano wszystkie święte obrzędy, stąd dla omawianej księgi przyjęła się łacińska nazwa Liber sacramentorum. W sakramentarzu nie było czytań i śpiewów, znajdowały się one bowiem w oddzielnych księgach przeznaczonych dla czytających i śpiewających w liturgii. Nie znajdziemy również w sakramentarzu wskazań dotyczących sposobu sprawowania obrzędów, czyli rubryk liturgicznych. Opisy obrzędów znajdują się w ordines.

Powstanie sakramentarza należy postrzegać na tle zmian zachodzących w liturgii rzymskiej od IV wieku. Wraz z uzyskaną wolnością rośnie wówczas liczba wiernych, a Kościół sprawuje już uroczystą liturgię w nowo powstałych bazylikach. Ze względów duszpasterskich w końcu IV wieku Kościół rzymski przechodzi ostatecznie w liturgii z języka greckiego na język łaciński. W całym Kościele dochodzi do zróżnicowania w sprawowaniu liturgii. Na Zachodzie także powstają rodziny liturgiczne. Dobiega końca czas modlitw improwizowanych, a tradycja ustna ustępuje modlitwom spisywanym. Nowa sytuacja wymaga 
uprzednio przygotowanych tekstów liturgicznych, nie wszyscy bowiem celebransi są zdolni do układania własnych modlitw. Do tego dochodzi troska o poprawność teologiczną modlitw oraz ich odpowiednią wartość literacką. Synody usiłują porządkować liturgię i wydają postanowienia dotyczące modlitw liturgicznych. Zalecają, aby kapłani konsultowali nowe teksty z braćmi lepiej przygotowanymi, oraz proponują swoje modlitwy i wymagają przedkładania nowych kompozycji osądowi Synodu. W tym czasie kształtuje się rok liturgiczny, który w Kościele zachodnim znajduje odbicie w zmiennych modlitwach mszalnych. Poszczególne dni liturgiczne otrzymują własne formularze. Pod koniec IV wieku zaczyna się czas ożywionej twórczości liturgicznej w Kościołach zachodnich, także w Kościele rzymskim.

Powstające nowe formularze spisywano i zachowywano w archiwum Kościoła lokalnego jako dokumentację i wzór na przyszłość, aby używać ich później w podobnych celebrach. Zbierane teksty tworzyły swego rodzaju książeczki mszalne, zwane dziś libelli missarum. Książeczka zawierała modlitwy celebransa przeznaczone na określoną celebrę albo też stanowiła mały zbiór wielu mszy. Książeczki mszalne przechodziły do innych kościołów, gdzie je kopiowano i dostosowywano do własnych potrzeb. Znaczenia nabierały teksty pochodzące od znanych i cenionych autorów. W IV i V wieku powstało w Rzymie wiele liturgicznych modlitw, które zostały odnalezione w sakramentarzach.

Sakramentarze powstawały ze względów praktycznych. Miały pomagać celebransowi w sprawowaniu liturgii. Celem nadrzędnym było jednak zapanowanie nad wielością i różnorodnością tekstów oraz wprowadzenie jednolitości w modlitwie Kościoła i przeżywaniu roku liturgicznego. Należy zauważyć, że tak jak sakramentarz zastąpił libelli missarum, tak z kolei sakramentarz zostanie zastąpiony przez mszał i właśnie teraz przechodzę do jego zaprezentowania.

Tematem drugiej księgi są katalogi rękopiśmiennych mszałów przedtrydenckich, względnie ich fragmentów. Jak wiadomo, mszał (Missale, liber missalis) to księga liturgiczna celebransa w stopniu biskupa lub prezbitera, służąca mu do sprawowania Mszy św., w której Kościół widzi źródło i szczyt swojego życia. Powstał on w średniowieczu na bazie sakramentarza gregoriańskiego. Stąd w ślad za katalogiem średniowiecznych sakramentarzy rękopiśmiennych przed chwilą Państwu tu zaprezentowa- 
nych Ks. Biskup opracował i wydał w tej samej serii sumaryczny wykaz przedtrydenckich mszałów rękopiśmiennych.

Wykaz ten opisuje 5079 mszałów lub ich zachowanych fragmentów. Powyższe rękopiśmienne źródła, szczegółowo opisane, pochodzą z 23 krajów i obejmują aż 614 miejscowości, zarówno w Europie, jak też w USA i Nowej Zelandii, a także z Polski (Częstochowa, Gdańsk, Gniezno, Kielce, Kraków, Lublin, Płock, Sandomierz, Warszawa, Włocławek, Wrocław).

Po raz pierwszy zatem w historii badań nad rękopisami powyższej epoki otrzymujemy niezwykły, monumentalny owoc wieloletnich poszukiwań, zapewne (prawie) całkowity sumaryczny katalog rękopiśmiennych mszałów przedtrydenckich.

Miejsca przechowywania analizowanych źródeł, które Autor dzieła nam precyzyjnie umiejscowił, są różnorakie. Podobnie jak w poprzednim dziele chodzi tu o archiwa, jak biblioteki krajowe, regionalne, miejskie, królewskie, książęce, uniwersyteckie, diecezjalne, katedralne, kapitulne, zakonne, parafialne itd. Ponadto każdy rękopiśmienny dokument opatrzony jest takimi precyzyjnymi danymi, jak: sygnatura, liczba kart rękopisu i ich wymiary podane w milimetrach, nazwa własna mszału bądź jego rodzaj, czas powstania dokumentu i miejsce jego pochodzenia, rok jego ewentualnego drukowanego wydania, zestaw bibliograficznych pozycji zawierających odniesienia do analizowanego dokumentu.

Zestaw pozycji bibliograficznych odnoszących się do określonych mszałów (lub ich fragmentów), wykorzystany i precyzyjnie podany przy jednostkowym kodeksie, obejmuje ponad dwa tysiące pozycji (!), publikowanych nie tylko w głównych europejskich językach (angielski, francuski, hiszpański, niemiecki, włoski), ale również w języku chorwackim, słoweńskim, a także polskim (zob. m.in. publikacje takich autorów jak Boguniowski, Dobrowolski, Kaliszczuk-Szyller, Miodońska, Nowowiejski Pikulik, Piwoński, Pośpiech, Różański, Rył, Sawicka, Schenk, Sokołowski, Święcki, Tabor, Trzciński, Witczak, Wolnik itd.).

Bibliografię oraz katalogi mszałów przedtrydenckich poprzedza obszerne wprowadzenie w postaci pogłębionego artykułu na temat rękopiśmiennych mszałów przedtrydenckich również autorstwa ks. prof. dra hab. Jana Miazka. Autor w sposób zwięzły, lecz niezwykle merytoryczny i kompetentny przedstawia ich genezę i rozwój od form pierwotnych do postaci występującej pod nazwą mszału pełnego (missale plenarium lub 
missale completum). Mszał pełny zawiera wszystkie teksty celebracji mszalnej: antyfony, czytania i modlitwy celebransa. Różni się od sakramentarza, w którym brak tekstów do czytań i śpiewów, ponieważ znajdowały się one w oddzielnych księgach (graduał, lekcjonarz, ewangeliarz), przeznaczonych dla osób czytających lub śpiewających podczas liturgii. Poza tym mszał dotyczy tylko celebracji mszalnej, natomiast sakramentarz uwzględnia także modlitwy związane z udzielaniem pozostałych sakramentów i sprawowaniem innych obrzędów. Wspólnym elementem sakramentarza i mszału pełnego są modlitwy celebransa sprawującego mszę św.

Początki mszału pełnego sięgają drugiej połowy IX wieku. Nowy typ księgi liturgicznej pojawił się najpierw w Italii Środkowej i Południowej. Powstanie mszału w wyniku połączenia w jednej księdze liturgicznej różnych ksiąg, istniejących wcześniej oddzielnie, następowało stopniowo. Zachowane manuskrypty uwidaczniają dokonującą się ewolucję, która jednak nie przebiegała wszędzie w sposób linearny. Poszczególne typy mszałów nie występują ściśle w porządku chronologicznym, czyli nie ma stopniowego przechodzenia od mszału prostego do księgi wypracowanej. Jak świadczą rękopisy, równocześnie powstawały i współistniały różne typy mszałów. Analiza manuskryptów pozwala zarówno na ich rozpoznanie, jak na odtworzenie drogi od sakramentarza do mszału pełnego.

Na podstawie zachowanych rękopisów można przyjąć, że ostatecznie mszał pełny został ukształtowany pod koniec XII wieku.

Jakie były przyczyny powstania mszału pełnego? Otóż na powstanie mszału pełnego wpłynęły okoliczności natury praktycznej, teologicznej i duszpasterskiej. Na pewno nie kierowano się tylko samym dążeniem do wygody celebransa. Genezę mszału pełnego należy widzieć na tle zmian w rozumieniu liturgii i duchowości kapłańskiej oraz w relacji do rozwoju sieci parafialnej.

Zapewne jedną z głównych przyczyn powstania mszału pełnego była praktyka odprawiania tzw. mszy prywatnych, sprawowanych przez kapłanów bez udziału ludu. Od czasów Grzegorza Wielkiego wzrasta w klasztorach liczba mnichów - kapłanów, którzy każdego dnia celebrowali msze św. w intencjach zmarłych. Powstawały także kaplice w siedzibach możnowładców i w domach prywatnych, obsługiwane przez jednego kapłana, co znacznie utrudniało sprawowanie uroczystej liturgii. Podobnie w małych kościołach diecezjalnych kapłani celebrowali msze z uprosz- 
czonymi obrzędami. Sami wykonywali czytania i sami odczytywali teksty przeznaczone do śpiewu przez schole. Wielu liturgistów utrzymuje, że na powstanie mszału pełnego decydująco lub wręcz wyłącznie wpłynęło upowszechnianie mszy prywatnych, czyli czytanych.

Na powstanie mszału pełnego miała wpływ także zmiana w rozumieniu natury liturgii. Odrębne księgi mszalne świadczą o jej wspólnotowym sprawowaniu. Wcześniej celebrans odmawiał jedynie modlitwy należące tylko do niego, lektor i diakon wykonywali czytania, schola śpiewał przepisane antyfony. Zgromadzona wspólnota uczestniczyła czynnie w liturgii. Natomiast w czasach pokarolińskich zmieniło się spojrzenie na Kościół i tym samym na jego liturgię. Kościół był już postrzegany jako wspólnota o wyrazistej strukturze hierarchicznej, a w konsekwencji także liturgia traktowana była przez wiernych jako czynność należąca do duchowieństwa. Niezrozumiały dla wiernych z ludu język łaciński powodował, że nie mogli oni w pełni świadomie uczestniczyć w liturgii. Udział wiernych polegał głównie na obecności na liturgii odprawianej dla nich przez kapłana. W tej sytuacji liturgia jawiła się jako czynność samego kapłana, a mszał stawał się księgą przeznaczoną wyłącznie dla niego.

Powstanie mszału należy również łączyć ze zmianami dokonującymi się w duszpasterstwie, zwłaszcza ze wzrostem liczby parafii oraz ich kościelnego znaczenia. Od XIII wieku mszał stawał się księga liturgiczną kościołów parafialnych i duchowieństwa parafialnego. Liturgia parafii małych, często odległych od centrum diecezji i ośrodków monastycznych, różniła się od rozbudowanych celebracji, sprawowanych w katedrach, w kolegiatach czy kościołach klasztornych. W parafiach sprawowano najczęściej msze czytane. Celebrans miał obowiązek recytowania wszystkich części formularza mszalnego, łącznie z antyfonami i czytaniami Pisma św. Podobnie obowiązek ten spoczywał na celebransie w uroczystej mszy śpiewanej w niedziele i święte. Z tego obowiązku wynikała potrzeba opracowania takiej księgi, która odpowiadałaby wymogom liturgii parafialnej

\section{EKSCELENCJE, SZANOWNI PAŃSTWO}

Obydwa monumentalne dzieła tu zaprezentowane są wyjątkowe z dwóch powodów: po pierwsze ze względu na oryginalną zawartość, substancję i po drugie ze względu na swoje rozmiary i szatę edytorską, 
która jest piękna, estetyczna i ciesząca wzrok. Zarówno treść, jak i oprawa obydwu dzieł wręcz onieśmiela każdego, kto bierze je do rąk. Techniczne gabaryty każdego z nich są niezwykłe i doskonale korespondują z ich zawartością. Wymiar dzieł - prawie A4 (dokładnie 28×21 cm), 1023 i 811 stron spięte bardzo solidną, trwałą, odpowiednią do rozmiarów i zawartości oprawą, „mocny i szlachetny papier”, czcionka, układ stron, paginacja, czytelny i logiczny podział materiału obiecują „długowieczność” tejże publikacji, by nie powiedzieć naukową nieśmiertelność! Za tę pięknie i solidnie przygotowaną oraz wykonaną stronę edytorską, iście wzorcową należy się Wydawnictwu Adama Marszałka w Toruniu wielkie uznanie i serdeczne podziękowanie.

Ale niezwykłość i oryginalność prezentowanych tu dzieł liturgicznych polega jeszcze na tym, że ich Autorem nie jest liturgista $\mathrm{z}$ wykształcenia, lecz biblista. Dla Księdza Biskupa Andrzeja Suskiego, wybitnego polskiego biblisty, liturgia zaraz po Biblii stała się drugim szczególnym przedmiotem naukowego zainteresowania, ambitnym hobby badawczym, ale także wielką życiową pasją i miłością. Myślę, że można z powodzeniem zastosować do Księdza Biskupa piękne adaggio Piusa Parscha, który powiedział o sobie: odkryłem w życiu trzy rzeczy: Biblię, liturgię i ich wzajemne powiązanie.

Nie chcąc być podejrzanym o subiektywną ocenę dzieła, chciałbym przytoczyć opinię jednego z najwybitniejszych aktualnie liturgistów - prof. Manlio Sodiego. Dzieło to to owoc di estrema pazienza e di accurata acribia e ricerca, autentico vademecum [...] di grande fatica [...] frutto di ricerche assidue e pazienti [...] una preziosa lectio anche per oggi e domani („owoc wyjątkowej cierpliwości i precyzyjnej dokładności oraz poszukiwań, autentyczny informator - przewodnik, owoc wielkiego wysiłku i systematycznych naukowych poszukiwań, cenna lekcja także na dzisiaj i jutro...”).

Zapewne „lata i wieki przeminą”, jak mówią słowa piosenki o Monte Cassino, lecz dzieło Ks. Biskupa będzie trwać niezmiennie, służąc całym pokoleniom historyków liturgii, znawcom paleografii czy choćby naukowcom zajmującym się średniowiecznym, rękopiśmiennym piśmiennictwem. Stanie się ono niewyczerpanym źródłem dla studentów teologii liturgii w prowadzonych przez nich badaniach naukowych. Głównie w zakresie szerokiego i pogłębionego studium euchologii i odkrywaniu w niej głębi 
wiary minionych pokoleń, zgodnie ze starożytną zasadą lex orandi lex credendi. Ale kodeksy Biskupa Andrzeja Suskiego - jak zauważa w swojej laudacji Rektor UMK - Pan prof. Andrzej Tretyn - będą służyły i są niezbędne także dla badaczy religii, kultury i sztuki. Łatwy dostęp do nich pomoże odkrywać i poznawać bogactwo różnych tradycji liturgicznych, piśmiennictwa danej epoki, a także religijnych zwyczajów ludowych charakterystycznych dla poszczególnych miejscowości, z których pochodzą i dla których wtedy powstały. Nade wszystko zaś niekwestionowana wartość źródeł polega na tym, że zawarta w nich treść teologiczno-liturgiczna będzie inspiracją i natchnieniem dla autorów nowych formuł modlitewnych i nowych tekstów liturgicznych, które nieustannie powstają w Kościele i są redagowane zgodnie ze współczesną myślą teologiczną, dostosowywane do aktualnych potrzeb duszpasterskich, mając zawsze na uwadze duchowe dobro wiernych.

Jestem głęboko przekonany, że to dzieło doczeka się nawet akronimu („skrótowca”) „Suski”, podobnie jak akronimy „Denzinger”, „Mansi”, „Bruns” i na zawsze wejdzie do panteonu nazwisk wielkich uczonych.

\section{EKSCELENCJO, NAJDOSTOJNIEJSZY KSIĘŻE BISKUPIE!}

Niech będzie mi wolno w imieniu całego środowiska naukowego Uniwersytetu Mikołaja Kopernika w Toruniu, w szczególności zaś Wydziału Teologicznego, a także Komitetu Nauk Teologicznych przy Polskiej Akademii Nauk, który reprezentuję, wyrazić słowa głębokiego uznania i szacunku, gratulacji i podziwu, serdecznego podziękowania i ogromnej wdzięczności za to imponujące dzieło. Właśnie podziwu i to nie tylko za jego stronę merytoryczną, wszak pracowitość i fachowość Księdza Biskupa są nam wszystkim bardzo dobrze znane, ale ze względu na kategorię czasu. Wszyscy pytamy, jak to możliwe, że sprawując tak niesłychanie ważny i absorbujący urząd w Kościele, jakim jest urząd biskupa diecezjalnego, można było równocześnie stworzyć tak monumentalne dzieło, opus magnum, wymagające iście mrówczej i benedyktyńskiej pracy, licznych wyjazdów do różnorakich ośrodków naukowych, zwłaszcza poza Polskę, no i właśnie czasu, ogromnego czasu. Ale to niech pozostanie dla nas tajemnicą! Dziękuję za uwagę! 
